\title{
AGRICULTURE AND RURAL LIFE IN FINLAND AND HUNGARY
}

A finn és magyar történészek közötti együttmüködés rendszeresen ismétlődő konferenciák, közös kiadványok formájában az 1970-es évek óta folyamatos, a két nemzet kutatóinak legalább három generációját érinti. A nyelvi rokonok gazdasági, kulturális, politikai, társadalmi fejlődési sajátosságai mindkét oldalon felkeltették az összehasonlító módszerek iránt fogékony és elkötelezett kutatók figyelmét, sőt alkalmanként más országok kutatói is publikáltak e két nemzet és állam történetének hasonlóságairól és különbségeiről. Milyen szakmai haszonnal járhat a két ország mezőgazdaság-történetének összehasonlítása? Mint az összehasonlító módszer esetében általában, itt is a másik vizsgálata mélyítheti, erősítheti az önismeretet. A most ismertetett kötet esetében az összehasonlítás kiindulópontja a 19. század vége, amikor a szerkesztők álláspontja szerint Finnország az északi országok fejlődési perifériájáról megkezdi a felzárkózást a kontinens iparosodó centrumához. Magyarországon ekkor még jobban érvényesülnek a feudális hagyományok mind a földtulajdon-, földbirtokviszonyokban, mind a politikai hatalom gyakorlásában. Az első világháború után a piacvesztések tekintetében nagyon közel kerül egymáshoz a két ország: Magyarország már nem exportálhatott élelmiszert a dualista Monarchia ötvenmilliós piacára, és összeomlott a finn ipari export fontos célpontja, Oroszország. Mindkét országban nagy volt az igen alacsony színvonalon élő agrárnépesség aránya, és egyszerre merült fel a földreform lehetősége mint a válságmenedzselés eszköze (a részletekről lásd Marchut Réka széles horizontú írását). Magyarországon a nagybirtokosok sikeres érdekérvényesítő képessége miatt megkésett és szerény mértékủ volt a reform, az önellátásra törekvő Finnországban a politika fő iránya sikeresen támogatta a kisparaszti gazdaságokat. Ugyanakkor hasonlóság, hogy mindkét országban a háborús válságból kivezető útnak része volt a mezőgazdaság fejlesztése. Magyarországon így erősödhetett meg az élelmiszeripar, Finnországban pedig az erdőmüvelésből származó jövedelem támogatta a kisbirtokosok tej- és tejtermék elóállító munkáját.

Sajátos hasonlóság a két ország között, hogy a mezőgazdaság és a mezőgazdasági lakosság szimbolikus kulcsszerephez jutott a nemzeti identitás folyamatos konstruálásában. A „hazafias paraszt” mítosza - Magyarországon a „kisgazda”, Finnországban a „szabad paraszt” formájában - mind Gustaf Mannerheim, mind Horthy Miklós számára a nemzetkép formálásának integráns része volt, noha e társadalmi réteg politikai befolyása csekély, jövedelmi, gazdasági helyzete az ipari munkásokénál is rosszabb volt. Drámaian eltért azonban egymástól a két ország a két világháború közötti időszak során a gazdasági növekedés ütemében 
és a társadalmi szerkezet modernizálásában. A finn gazdasági növekedés üteme a leggyorsabbak közé számított Európában, és a szociáldemokrata-agrárpárti koalíció harmonizálta az ipari és mezőgazdasági dolgozók érdekeit, az állami beavatkozás a földtulajdonviszonyokba a társadalmi békét segítette. Magyarországon az állam nem volt képes és nem is szándékozta jelentősen korlátozni a nagybirtok gazdasági szerepét. A különbségek csak nőttek a II. világháború után: hiába volt Magyarországon radikális földreform, az államnak nem voltak forrásai a sok kisgazda megsegítésére. Ugyanekkor Finnországban a formálódó jóléti állam még 420000 Karéliából elüldözött menekült elhelyezésére is talált megoldást (lásd erről Erki Laitinen tanulmányát). Magyarországon a sztálinista agrárpolitika katasztrofális következményekkel járt, a mezőgazdaság az erőszakos kollektivizálás, valamint a túlzott mértékủ és ütemű iparosítás áldozata lett. Az ebből fakadó társadalmi és politikai feszültségek hozzájárultak az 1956-os forradalom kirobbanásához. A forradalom tanulsága mérsékletre intette a Kádár-rendszert, de az újraszervezett és modern gépekkel felszerelt termelöszövetkezetek maradtak a mezőgazdasági termelés meghatározó szervezeti keretei. Finnországban a termelés technikai és szervezeti modernizálása a kis farmokon zajlott le. A magyarországi helyzetet színezte a politikai vezetésben kialakult agrárlobby. Az 1960-as és 1970-es évek fordulójától kezdve mennyiségben és minőségben is eröre kapott az élelmiszertermelés, konszolidálódott az agrártársadalom helyzete. Erre az időszakra Finnországban is megerösödtek a szövetkezetek. Az 1980-as években azonban eltérö irányokat vett a két ország agrárfejlődése: a 70-es években kialakult struktúra Finnországban növekedő hatékonyságot, termelékenységet eredményezett, Magyarországon az ipart preferáló, szocialista ideológiára építő gazdaságpolitika gyengítette a mezőgazdaság pozícióit. A szovjet rendszer és így a szovjet piac összeomlása mindkét ország agráriuma számára nagy kihívást jelentett. A magyarországi, politikai indíttatású kárpótlás eredményeként igen sok apró, hatékony gazdálkodásra alkalmatlan kisbirtok jött létre, de a 21. század elejére mindkét országban igen kis számú nagybirtokos kezében centralizálódott a mezőgazdasági termelés. A siker titka a hagyományos szakmai tudás mellett egyre inkább az Európai Unió mezőgazdasági politikájának, bürokráciájának kiismerése, a céltudatos lobbyzás lett mindkét országban. Mindezt, a finn és a magyar huszadik századi agrárfejlődés fő vonalait, igen világosan és lényegre törően Varga Zsuzsanna és Anssi Halmesvirta összefogottan érvelő bevezető tanulmánya foglalja össze. Az egyes részkérdéseket öt finn, hat magyar és egy német történész tanulmányai dolgozták fel. Módszertanilag, szemléletileg egységes a tizenegy tanulmány, értelmezésükben az agrártörténet jóval több a mezőgazdasági termelés történeténél, magában foglal eszme- és társadalomtörténeti mozzanatokat, s nemegyszer - így az e könyvben tárgyalt két nemzet estében is - a nemzeti-etnikai kisebbségek szempontjaira is figyelnie kell. 
S éppen ezért ez a kötet sem csupán az agrártörténészek (akik közé e sorok írója sem tartozik) érdeklődésére tarthat számot. Melyek azok a kérdések, amelyekről a kötetet elolvasva a legtöbb új információhoz, szemponthoz juthatunk?

Egyszerủnek tűnő alapkérdés, de korántsem egyértelmủ a paraszt, parasztság fogalom mindkét országra érvényes fogalmának tisztázása. Nyugat-európai (s ebben az összehasonlításban Finnország a Nyugat része) értelemben a magyar mezőgazdasági népesség kétharmada nem számított parasztnak (s a peasant, Bauer vagy paysan s feltételezésem szerint a talonpoika szónak sincs olyan gyakran használt minősítő értéktartalma, mint a magyar paraszt kifejezésnek), mivel bérmunkára kényszerültek. Általában a törpebirtokosoknak - függetlenségük révén - nagyobb a társadalmi tekintélyük, elfogadottságuk, mint az akár lényegesen nagyobb jövedelmű bérmunkásoknak, napszámosoknak. Társadalom- és eszmetörténeti elemzések, így Papp István, Tóth Tibor, Tóth Judit írásai, is körbejárják e témakört. Elgondolkoztatóak a könyvben található fejtegetések a farmok, földbirtokok optimális mértékéről. Olvashatunk arról, hogy milyen alacsony hatékonysággal müködnek a modern technikát nélkülözni kénytelen apró birtokok, de a másik véglet, így például, amikor a mai Magyarországon a megművelhető földterület 75 százaléka a birtokosok 3 százaléka kezében van, is számos gazdasági, társadalmi és politikai feszültséget okozhat (Varga Zsuzsanna, Jorma Wilmi). Sok mai, a falusi életet kevéssé ismerő városlakó gondol nosztalgiával a rurális mindennapokra, ennek realitásait elemzi oral history interjúk alapján Pilvi Hameenah. Az 1956 utáni magyar agrártársadalom, a kádári Magyarország Holger Fischer által elemzett sajátos jelensége volt a termelöszövetkezetek ipari és szolgáltató melléküzemágainak kibontakozása az 1960-as évek végétől. Az ebben a szervezeti formában zajló munka általában hatékonyabb és jövedelmezőbb volt a mezőgazdasági fötevékenységnél, és a piacgazdaság logikáját vitte a központosított gazdaságirányítási rendszerbe. A társadalmi normák, értékek változásairól érdekes esettanulmány Porkoláb Péter elemzése a társadalmi együttműködés formáiról egy kis nyírségi faluban. A sok generációra visszatekintő kölcsönös segítségnyújtás, spontán és szervezett együttlétek, közös ünnepek a rendszerváltás után kezdtek háttérbe szorulni, a sztenderdizálásra törekvő bürokratikus szabályozások a civil társadalom sokszínűségét figyelmen kívül hagyva inkább fegyelmezett adóalanyokban gondolkodnak.

Egyes előrejelzések szerint 2050-re a világ lakosságának 70 százaléka fog városokban élni (ez az arány Magyarországon már a mai helyzet), az élelmiszertermelés egyre inkább iparszerüvé válik, a kötet sok gondolatot ébreszt arról, hogy hol lesz a helyük ezekben a társadalmakban az agrártársadalmakban gyökeredző tradícióknak.

Valamennyi tanulmány azt bizonyítja, hogy az agrártörténet nem pusztán a mezőgazdasági technikák és az agrártársadalom leíró története, hanem a falusi világ egészének elhelyezése a tágabb értelemben vett történelemben. A könyv 
olvasásakor egyértelművé válik, hogy míg a magyar mezőgazdaságot a megszakítottságok és problémák övezték, addig a finn agráriumra a sikerek voltak jellemzők, ez pedig a két ország általános eredményességével is összefügg. Ha szeretnénk megérteni, miben gyökerezik az, hogy ma Finnország a világ egyik legmodernebb országa, érdemes tanulmányoznunk ezt a könyvet.

(Zsuzsanna Varga - Anssi Halmesvirta editors: Agriculture and Rural Life in Finland and Hungary. Sarka - the Finnish Museum of Agriculture, 2018, 182 o.)

Pók Attila

történész 